\title{
Studies on the Biochemical Basis of the Minimum Temperatures for Growth of Gertain Psychrophilic and Mesophilic Micro-organisms
}

\author{
By A. H. ROSE AND LILIAN M. EVISON \\ Department of Microbiology, The University, Newcastle upon Tyne
}

(Received 21 August 1964)

\begin{abstract}
SUMMARY
Growth, respiratory activity and the ability to accumulate D-glucosamine were examined in three psychrophilic and three related mesophilic micro-organisms at temperatures between $0^{\circ}$ and $20^{\circ}$. Each of the psychrophils (strains of Arthrobacter, Candida and Corynebacterium erythrogenes) grew well at $0^{\circ}$ and also respired exogenous glucose and accumulated glucosamine at this temperature. The minimum temperatures for growth $\left(5-10^{\circ}\right)$ of the mesophilic strains of Arthrobacter and Candida utilis were approximately the same as those at which the organisms ceased to respire glucose and accumulate glucosamine. But the mesophil Corynebacterium xerosis respired exogenous glucose and accumulated glucosamine at temperatures as low as $10^{\circ}$, which is well below the minimum temperature for growth of this bacterium in freshly inoculated culture $\left(20^{\circ}\right)$. Cultures of C. xerosis transferred from $30^{\circ}$ to $15^{\circ}$ in the mid-exponential phase of growth were capable of a limited amount of growth at the lower temperature, corresponding approximately to a doubling in the size of the population; late-exponential phase cultures when transferred to $15^{\circ}$ did not have this ability. Although cultures of C. xerosis transferred from $30^{\circ}$ to $10^{\circ}$ did not grow, the bacteria were able to respire exogenous glucose and accumulate glucosamine even after $48 \mathrm{hr}$ at the lower temperature. The psychrophilic organisms did not differ from their mesophilic counterparts in their sensitivity to 2,4-dinitrophenol, uranyl ions and nystatin, three metabolic inhibitors which affect respiratory activity and sugar uptake in microorganisms.
\end{abstract}

\section{INTRODUCTION}

Many micro-organisms fail to multiply when incubated at temperatures below $5-10^{\circ}$. These organisms have been described as mesophilic to distinguish them from psychrophilic micro-organisms which grow well at temperatures as low as, and sometimes lower than, $0^{\circ}$. The biochemical factors which determine the minimum temperatures for the growth of micro-organisms have only recently been explored although the problem was stated quite succinctly by Rahn many years ago when he observed that, since growth and respiration are chemical reactions, they should continue though at a greatly decreased rate until the medium in which the microorganisms are suspended freezes solid (Rahn, 1932). Although this behaviour is found with psychrophilic micro-organisms, it is not characteristic of mesophils.

Ingraham (1958) compared the effect of incubation temperature on the generation times of a psychrophilic and a mesophilic bacterium, and showed that the psychrophil had a lower temperature characteristic (a value which is synonymous with $\mu$ 
of the Arrhenius equation) as compared with the mesophil. This difference in temperature characteristic prompted Ingraham \& Bailey (1959) to examine the effect of heat on the activities of glucose 6-phosphate-, isocitrate-, and malatedehydrogenases in cell-free extracts of these bacteria, to discover whether the enzymes in the psychrophil had lower activation energies than the corresponding enzymes from the mesophil. It was found, however, that the activation energies were very similar if not identical for the enzymes examined. But, in other experiments, it was shown that the temperature coefficient (i.e. $\boldsymbol{Q}_{10}$ value) of glucose oxidation was less for the psychrophil than for the mesophil, and these findings led Ingraham \& Bailey (1959) to suggest that the differences in temperature response between psychrophils and mesophils might be the result of differences in some aspect of the biochemical organization of the organisms rather than in the properties of individual enzymes. The first indication of an aspect of cell organization which might form the basis of the difference in response to near-zero temperatures came from a report by Baxter \& Gibbons (1962). These workers compared the respiratory activities of a psychrophilic strain of Candida, a yeast, with a mesophilic strain of Candida lipolytica and found that the psychrophil respired endogenous reserves at a greater rate than the mesophil at all temperatures up to $30^{\circ}$ and that, although the psychrophil oxidized glucose at an appreciable rate even at $0^{\circ}$, virtually no exogenous substrate was oxidized by the mesophil at temperatures below $5^{\circ}$. Baxter \& Gibbons suggested that the main factors determining the minimum temperature for growth of a micro-organism are the temperature characteristics of the mechanisms for transporting solutes into the organisms.

The present paper describes experiments on the effect of temperatures between $0^{\circ}$ and $20^{\circ}$ on the growth, respiratory activity and glucosamine-accumulating capacity of three psychrophilic and three related mesophilic micro-organisms. These experiments were done to assess the extent to which the temperature characteristics of the solute transport mechanisms determine the minimum temperatures for growth of these organisms.

\section{METHODS}

Organisms. The psychrophilic micro-organisms used were Arthrobacter strain No. R 22/3A (provided by Mr S. B. Thomas, National Agricultural Advisory Service, Ministry of Agriculture, Fisheries and Food, Trawscoed, Aberystwyth, Wales), Candida strain No. A 3 E-2 (Straka \& Stokes, 1960; obtained through the courtesy of Dr R.P. Straka, Western Utilization Research and Development Division, U.S. Department of Agriculture, Albany, California, U.S.A.) and Corynebacterium erythrogenes strain NCMB 5 . The mesophilic counterparts of these organisms were Arthrobacter strain No. 16 (Veldkamp, Van Den Berg \& Zevenhuizen, 1963; supplied by Professor H. Veldkamp, Bacteriology-Serology Laboratory, University of Groningen, Holland), Candida utilis strain NCYC 321, and three strains of Corynebacterium xerosis, one (strain NCL) from the culture collection in this department, and the other strains NCTC 7243 and 9755.

The strains of Candida were maintained on slopes of malt wort agar $(10 \%, \mathrm{w} / \mathrm{v}$, spray-dried malt extract, 'Muntona', Munton \& Fison, Ltd., Stowmarket, Suffolk, $+2 \%, \mathrm{w} / \mathrm{v}$, agar) and the bacteria on nutrient agar. Stock cultures of the psychrophils were stored at $0^{\circ}$ and the mesophils at room temperature $\left(18^{\circ}-20^{\circ}\right)$. 
Experimental cultures. The glucose + salts + vitamins medium ( $\mathrm{pH} \mathrm{4.5)}$ of Rose \& Nickerson (1956) supplemented with D-biotin (2.0 $\mu \mathrm{g}$./1.) was used for growing the yeasts. The bacteria were grown in a medium ( $\mathrm{pH} 6 \cdot 7)$ of the following composition: glucose, 20.0 g.; Casamino acids, vitamin-free (Difco), $10 \cdot 0$ g.; $\mathrm{Na}_{2} \mathrm{HPO}_{4}, 6.0$ g.; $\mathrm{KH}_{2} \mathrm{PO}_{4}, 3.0$ g.; $\mathrm{NaCl}, 3.0 \mathrm{~g}$; $\mathrm{NH}_{4} \mathrm{Cl}, 2.0$ g.; $\mathrm{MgSO}_{4} .7 \mathrm{H}_{2} \mathrm{O}, 0 \cdot 1 \mathrm{~g}$., L-cysteine, $0.1 \mathrm{~g}$; ; DL-tryptophan, $0.1 \mathrm{~g}$.; nicotinic acid, $4 \cdot 0 \mathrm{mg}$.; thiamine, $1.0 \mathrm{mg}$.; calcium-Dpantothenate, $1.0 \mathrm{mg}$; pyridoxin $\mathrm{HCl}, 1.0 \mathrm{mg}$.; riboflavin, $0.25 \mathrm{mg}$.; D-biotin, $\mathbf{2} \cdot \mathbf{0} \mu \mathrm{g}$; distilled water, $1 \mathrm{l}$.

Portions (100 ml.) of yeast medium or of glucose-free bacterial medium $(90 \mathrm{ml}$.) were dispensed into $350 \mathrm{ml}$. conical flasks plugged with cottonwool. Yeast medium was sterilized by autoclaving momentarily at $110^{\circ}$ and bacterial medium at $115^{\circ}$ for $15 \mathrm{~min}$. After cooling, each portion of bacterial medium was supplemented with $10 \mathrm{ml}$. of sterile $20 \%$ (w/v) glucose solution. In certain experiments, cultures (6 ml.) were grown in Samco tubes covered with anodized aluminium caps (Oxo Ltd., Queen Street Place, London, E.C. 4; Northam \& Norris, 1951). Yeast inocula were prepared by suspending sufficient organisms from a slope culture into $6 \mathrm{ml}$. phosphate buffer ( $\mathrm{M} / 15 \mathrm{KH}_{2} \mathrm{PO}_{4} ; \mathrm{pH} \mathrm{4.5)}$ to give a concentration equivalent to $0.07-0.09 \mathrm{mg}$. dry wt./ml. With bacterial inocula, the organisms were suspended in $6 \mathrm{ml} .0 \cdot 85 \%(\mathrm{w} / \mathrm{v})$ $\mathrm{NaCl}$ to give a concentration equivalent to 0.05-0.07 mg. dry wt./ml. The organisms in suspensions were washed twice with sterile buffer or saline and resuspended in a final $6 \mathrm{ml}$. portion. Each flask of sterile medium was inoculated with $0.8 \mathrm{ml}$. of washed suspension and each tube $(6 \mathrm{ml}$.) with $0.05 \mathrm{ml}$. suspension. Growth of the organisms was measured turbidimetrically in Samco tubes with the Hilger 'Spekker' absorptiometer (Model $\mathrm{H} \mathrm{760)}$ ) and neutral green-grey $\mathrm{H} 508$ filters, and a medium blank. Turbidity readings were related to dry weight of organism by using a calibration curve for each organism. It was shown, with each of the organisms used in this study, that the temperature of incubation did not alter the relationship between the turbidity of the culture and the equivalent dry weight of organisms present or their deoxyribonucleic acid content as determined by the method described by Ahmad, Rose \& Garg (1961).

Cell suspensions. After growth had been measured, organisms were separated from culture fluid by centrifugation. Yeast crops were washed three times with phosphate buffer ( $\mathrm{pH} 4.5$ ) and bacteria with phosphate buffer ( $\mathrm{pH} \mathrm{7.0;} \mathrm{Gomori,}$ 1955). During centrifugation and washing, the organisms were maintained at the same temperature as that at which they had been incubated.

Respirometry. Determinations of the rates of respiration of endogenous reserves $\left(Q_{\mathrm{O}_{2} \text { end. }}\right)$ and of exogenous glucose $\left(Q_{\mathrm{o}_{2} \text { gluc. }}\right)$ at different temperatures were made by the direct Warburg method (Umbreit, Burris \& Stauffer, 1957) by using the Braun Warburg apparatus (Model V 85; B. Braun, Melsungen, West Germany) fitted with cooling coils. Each flask contained the equivalent of between 2 and $12 \mathrm{mg}$. dry-weight washed organism in $2.0 \mathrm{ml}$. of phosphate buffer ( $\mathrm{pH} \mathrm{4.5)}$ with the yeasts or phosphate buffer $(\mathrm{pH} \mathrm{7 \cdot 0)}$ with the bacteria. The centre well contained $0.2 \mathrm{ml} .20 \%(\mathrm{w} / \mathrm{v}) \mathrm{KOH}$ and the side arm $0.3 \mathrm{ml} .10 \%(\mathrm{w} / \mathrm{v})$ glucose or $0.3 \mathrm{ml}$. water. Air was the gas phase. The $Q_{\mathrm{O}_{2} \text { end. }}$ and $\boldsymbol{Q}_{\mathrm{o}_{2} \text { gluc. }}$ values are expressed as the number of $\mu \mathrm{l}$. oxygen consumed/mg. dry wt. organism/hr at the temperature stated.

Measurement of glucosamine uptake. Transport of sugar into the micro-organisms 
was studied by measuring their capacity to accumulate D-glucosamine. It was possible to use this amino sugar since none of the organisms utilized it as a carbon or nitrogen source for growth. Portions of a suspension containing the equivalent of 40$50 \mathrm{mg}$. dry wt. organism were centrifuged at the appropriate temperature and the organisms resuspended in $15 \mathrm{ml}$. of phosphate buffer ( $\mathrm{pH} 4.5$ or $\% \cdot 0$ ) containing $\mathbf{1 . 2} \%(\mathrm{w} / \mathrm{v}) \mathrm{D}$-glucosamine $\mathrm{HCl}$. Control suspensions were prepared in phosphate buffer lacking glucosamine. In certain experiments, 2,4-dinitrophenol (DNP; mM) was included in the suspending buffer. The portions of buffer were equilibrated at the appropriate temperature before being used. The suspensions were placed in $50 \mathrm{ml}$. conical flasks and stirred with a magnetic stirrer for $2 \mathrm{hr}$ at a constant temperature. A portion (6 ml.) of each suspension was removed after $2 \mathrm{hr}$, and these portions were rapidly transferred to ice-cold tubes and centrifuged on a high-speed centrifuge at $0^{\circ}$. The organisms in the pellets were washed three times with ice-cold water, and finally suspended in $3 \mathrm{ml}$. water and placed in a boiling water bath for $10 \mathrm{~min}$. On cooling, the debris in the boiled suspensions was removed by centrifugation and, after being supplemented by washings from the debris, the supernatant fluid was made up to $5 \mathrm{ml}$. and assayed for glucosamine by the method of Rondle \& Morgan (1955). It is possible that some of the glucosamine transported into the organisms was phosphorylated, but Burger \& Hejmova (1961) and Cirillo, Wilkins \& Anton (1963) showed that this does not affect the chemical estimation of the sugar in extracts of the micro-organisms. The results are expressed as the number of $\mu \mathrm{g}$. D-glucosamine accumulated $/ \mathrm{mg}$. dry-weight organism $/ \mathrm{hr}$ at the temperature stated.

\section{RESULTS}

Effect of incubation temperature on growth, respiration and glucosamine accumulation

Initially an examination was made of the effect of temperatures of incubation between $0^{\circ}$ and $20^{\circ}$ on growth of each of the six organisms and on their ability to respire endogenous reserves $\left(Q_{\mathrm{o}_{2} \text { end. }}\right)$ and exogenous glucose $\left(Q_{\mathrm{o}_{\mathbf{2}} \text { gluc. }}\right)$. The results (Fig. 1) showed that with all six organisms the values for $Q_{0_{2} \text { end. }}$ decreased as the temperature was lowered, but, at $0^{\circ}$, the value was finite and ranged from 0.5 for Corynebacterium xerosis to 4.7 for $C$. erythrogenes. Over the range $10^{\circ}-20^{\circ}$, temperature coefficient $\left(Q_{10}\right)$ values for endogenous respiration were higher for the mesophils (ranging from $\mathbf{2 \cdot 3}$ for Candida utilis to $\mathbf{3 \cdot 2}$ for C. xerosis) than for the psychrophils (which ranged from $1 \cdot 3$ to $1 \cdot 8$ ). The values for $Q_{\mathrm{o}_{2} \text { gluc, }}$ also decreased as the temperature was lowered. With each of the psychrophilic organisms, there was a detectable respiration of exogenous glucose at $0^{\circ}$, and the $Q_{\mathrm{o}_{2} \text { gluc. values at }}$ this temperature ranged from $0 \cdot 7$ for Arthrobacter R 22/3 A to 3.2 for the psychrophilic Candida strain. But, with the three mesophilic organisms, there was negligible respiration of exogenous glucose at temperatures below about $5^{\circ}$. The temperature

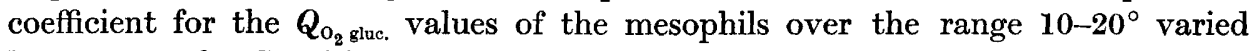
between $6 \cdot 3$ for $C$. utilis to $12 \cdot 6$ for Arthrobacter 16 but were much lower (between 1.5 and $2 \cdot 7$ ) for the psychrophils. These differences in the temperature coefficients of the $Q_{\mathrm{O}_{2}}$ values were therefore in general agreement with the data reported by Ingraham \& Bailey (1959). The rate of growth also declined as the temperature of incubation was lowered. All of the psychrophilic organisms grew well at $0^{\circ}$ but the minimum temperature for growth of the mesophils was higher. With $C$. utilis and 
Arthrobacter 16, the minimum temperature was approximately the same as that at which the $Q_{\mathrm{O}_{2} \text { gluc. }}$ values approached zero. With C. xerosis, however, the minimum temperature for growth (about $20^{\circ}$ ) was much higher than the temperature at which the $\mathbf{Q}_{\mathbf{O}_{\mathbf{2}} \text { gluc. }}$ values for this organism fell to zero.

Arthrobacter 16

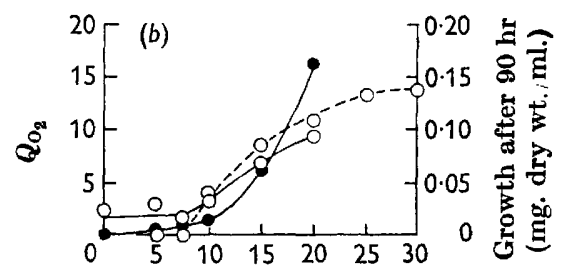

Temperature $\left(^{\circ}\right)$

\section{Candida utilis NCYC 321}

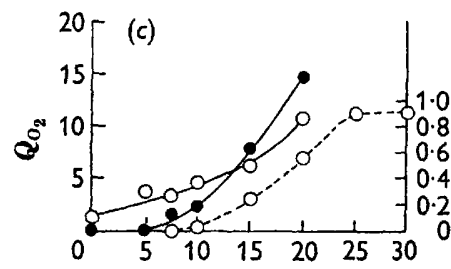

Temperature $\left({ }^{\circ}\right)$

Corynebacterium xerosis NCL

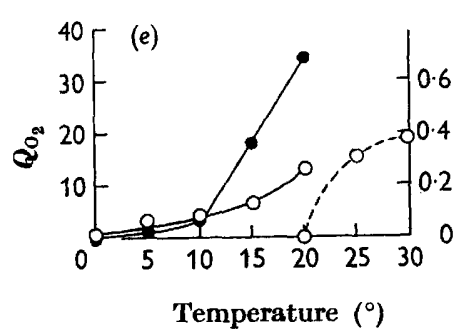

Arthrobacter R 22/3 A

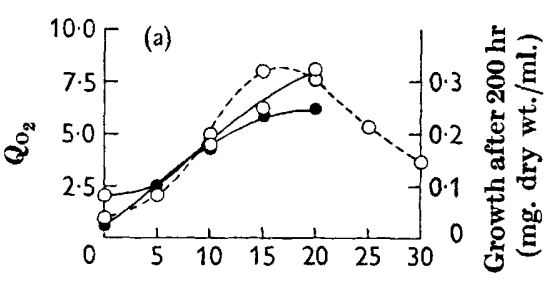

Temperature $\left({ }^{\circ}\right)$

Candida A 3 E-2

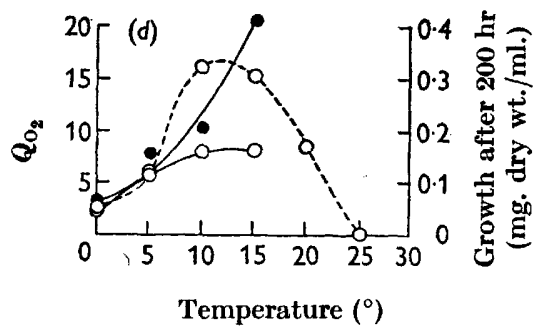

Corynebacterium erythrogens $\mathrm{NCMB} 5$

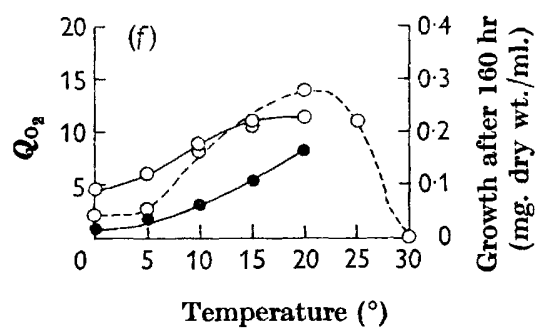

Fig. $1(a)$ to $(f)$. Effect of temperature of incubation on growth and on the respiration of endogenous reserves and of exogenous glucose by certain psychrophilic and mesophilic micro-organisms. Growth $\left(\mathrm{O}_{-}-\mathrm{O}_{\mathrm{O}}\right)$ at the different temperatures was measured at a time at which cultures incubated at the optimum temperature for growth were in the late-exponential phase. Measurements of respiratory activity were made on organisms grown at the following temperatures which are at or near the optimum for growth; psychrophils : (b) Arthrobacter $\mathrm{R} 22 / 3 \mathrm{~A}, 20^{\circ} ;(d)$ Candida A $3 \mathrm{E}-2,10^{\circ} ;(f)$ Corynebacterium erythrogenes, $20^{\circ}$; mesophils: (a) Arthrobacter 16, $30^{\circ}$; (c) Candida utilus, $25^{\circ}$; (e) Corynebacterium xerosis strain $N C L, 30^{\circ}$. When cultures at these temperatures had reached the mid-exponential phase of growth, organisms were harvested and washed in phosphate buffer ( $\mathrm{pH} 4.5$ for the yeasts; $\mathrm{pH} \mathrm{7.0}$ for the bacteria). During washing, the organisms were maintained at the temperature at which they had been incubated. Portions of the washed suspensions, containing known concentations of organisms (mg. dry wt. equivalent/ml.) were placed in Warburg flasks and the $Q_{\mathrm{O}_{2}}$ values ( $\mu$ l. oxygen consumed/ mg. dry wt. organism/hr) were determined as described under Methods for the respiration of endogenous reserves $(\mathrm{O}-\mathrm{O})$ and of exogenous glucose $(\mathrm{O}-\mathrm{O})$. 
When an examination was made of the effect of temperatures between $0^{\circ}$ and $20^{\circ}$ on the capacity of each organism to accumulate glucosamine, it was found that this property was affected in the same way as the ability to respire exogenous glucose. This suggested that the inability of the mesophilic micro-organisms to respire exogenous glucose at temperatures below about $5^{\circ}$ was a result of their not being able to transport sugars into the organisms at these temperatures.

Table 1. Effect of treatment with aqueous butanol on the respiratory activity of Candida utilis at $5^{\circ}$

\begin{abstract}
The yeast was harvested from $40 \mathrm{hr}$ cultures grown at $\mathbf{2 5}^{\circ}$, washed three times in phosphate buffer (pH 4.5) and suspended in this buffer to equiv. $18 \mathrm{mg}$. dry wt. yeast/ml. Portions of this suspension were centrifuged at room temperature and the supernatant fluids removed. The yeast pellet was then suspended in a volume of phosphate buffer, or of $2 \%$ or $5 \%, v / v, n$-butanol in phosphate buffer, equal to that of the original portion of suspension. The suspensions were centrifuged immediately at room temperature and the organisms resuspended in an equal volume of buffer. Portions of these suspensions were then placed in Warburg flasks and the respiratory activity of the organisms measured at $5^{\circ}$ as described in Methods.
\end{abstract}

\begin{tabular}{|c|c|c|}
\hline \multirow{2}{*}{$\begin{array}{c}\text { Concentration of } \\
n \text {-butanol in } \\
\text { phosphate } \\
\text { buffer } \\
(\%, v / v)\end{array}$} & \multicolumn{2}{|c|}{ Respiratory activity } \\
\hline & $Q_{\mathrm{O}_{2} \text { end. }}$ & $Q_{\mathrm{O}_{2} \text { gluc }}$ \\
\hline $0 \cdot 0$ & $3 \cdot 6$ & 0.0 \\
\hline $2 \cdot 0$ & 3.2 & $1 \cdot 1$ \\
\hline 5.0 & $1 \cdot 6$ & 0.7 \\
\hline
\end{tabular}

The correlation between the effect of low temperatures on the ability of the mesophilic strains of Arthrobacter and Candida to grow in freshly inoculated culture and their capacity to respire exogenous glucose and to accumulate glucosamine lent support to the hypothesis of Baxter \& Gibbons (1962) that the minimum temperatures for growth of micro-organisms are determined by the temperatures at which the mechanisms for transporting solutes into the organisms are inactivated. Further evidence to support this hypothesis came from experiments in which Candida utilis was treated with aqueous butanol before measurements were made on its respiratory activity. Treatment with aqueous butanol $(2-5 \%, v / v)$ breaks the osmotic barrier in micro-organisms and permits the free diffusion into organisms of solutes permeation of which normally requires the intervention of specific transport mechanisms (Mitchell \& Moyle, 1956; Rose, 1963). When C. utilis was washed, rapidly suspended in $3 \%$ or $5 \%(\mathrm{v} / \mathrm{v}) n$-butanol in phosphate buffer (pH 4.5), centrifuged, resuspended in buffer and added to a Warburg vessel, there

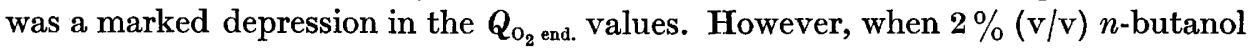
in phosphate buffer ( $\mathrm{pH} \mathrm{4.5)}$ was used, the respiration of endogenous reserves by the yeast was much less affected, and the yeast respired glucose at $5^{\circ}$, at which temperature there was no detectable respiration of exogenous glucose in untreated yeast (Table 1).

\title{
Effect of inhibitors on sugar transport
}

Because of the observed differences in the effect of incubation temperature on the activity of the mechanisms for transporting sugars into mesophilic and psychro- 
philic micro-organisms, further experiments were made to discover any other differences in the properties of the sugar transport processes in these two groups of micro-organisms. 2,4-Dinitrophenol (DNP), which uncouples respiration and oxidative phosphorylation, has been shown to inhibit 'uphill' transport of many sugars into micro-organisms (Cirillo, 1961). An examination of the effect of DNP on respiration and on glucosamine accumulation by each of the six organisms

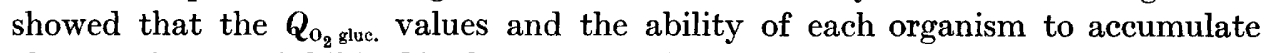
glucosamine were inhibited in the presence of DNP ( $\mathrm{mM})$. The extent of the inhibition varied with each organism but was not markedly different with the psychrophils as compared with the mesophils.

Uranyl ion, in the form of uranyl nitrate at mu concentration, inhibits transport of sugars (Cochrane \& Tull, 1958) and amino acids (Gale, 1954) into bacteria, yeasts and filamentous fungi. The ion, which is presumed to act by combining with phosphate groups on molecules in the cytoplasmic membrane, does not affect the respiration of endogenous reserves by micro-organisms. The effect of $\mathrm{UO}_{2}^{2+}(\mathrm{mm})$ on the respiration of each of the six organisms was examined at several temperatures above and below the minimum for growth. Respiration of exogenous glucose was completely suppressed by $\mathrm{UO}_{2}^{2+}$ in all organisms but the ion had no detectable effect on the endogenous respiration at any of the temperatures employed.

The polyene antibiotic nystatin acts on yeasts and filamentous fungi and causes changes in the permeability properties of the cytoplasmic membranes (Marini, Arnow \& Lampen, 1961). The antibiotic acts by combining with sterols in the membrane (Lampen, Arnow, Borowska \& Laskin, 1962); bacteria, which do not contain sterols, are therefore not sensitive to polyene antibiotics. Respiration of the mesophilic and psychrophilic strains of Candida was depressed by nystatin (Squibb 'Mycostatin'; 0.22 $\mathrm{mg}$./ml. in dimethyl sulphoxide) at temperatures above and below the minimum for growth. But the antibiotic was without effect on the respiratory activities of any of the bacteria at temperatures above or below the minimum for growth.

\section{Growth, respiration and glucosamine accumulation by Corynebacterium xerosis at various temperatures}

The inability of two of the three mesophilic micro-organisms to respire exogenous glucose and accumulate glucosamine at temperatures below the minimum for growth in freshly inoculated culture, suggested that inactivation of the sugar transport mechanisms occurred rapidly following the transfer of these organisms to temperatures between $10^{\circ}$ and $0^{\circ}$. On the other hand, the NCL strain of Corynebacterium xerosis, which was unable to grow in freshly inoculated culture at temperatures below about $20^{\circ}$, respired exogenous glucose and accumulated glucosamine at temperatures as low as about $8^{\circ}$. This behaviour was not peculiar to the NCL strain of $C$. xerosis since two other strains of this bacterium (NCTC 7243, 9755) were shown to have minimum temperatures for growth of about $20^{\circ}$ in defined medium and to behave similarly to the NCL strain with regard to the effect of temperature on their ability to respire endogenous reserves and exogenous glucose. Bergey's Manual (1957) reports that high minimum temperatures for growth are characteristic of $C$. xerosis. It was conceivable that this behaviour of $C$. xerosis was due to a comparatively slow inactivation of the sugar transport mechanisms at 
Table 2. Respiratory activity and glucosamine-accumulating capacity of Corynebacterium xerosis strain NCL following transfer from $30^{\circ}$ to $10^{\circ}$

Cultures of the C. xerosis were grown at $30^{\circ}$ and after $40 \mathrm{hr}$, when they had reached the mid-exponential phase of growth, certain of the cultures were transferred to $10^{\circ}$. There was no detectable growth of the cultures at $10^{\circ}$. At the time of transfer and after a further 24 and $48 \mathrm{hr}$, cultures were removed from $30^{\circ}$ and $10^{\circ}$ and the bacteria harvested by centrifugation, during which they were maintained at the temperature at which they had been incubated. The bacteria were then washed with phosphate buffer $(\mathrm{pH} 7 \cdot 0)$ and portions of the washed suspension containing the equivalent of a known dry weight of bacteria were placed in Warburg flasks and the respiratory activity of the bacteria determined at $30^{\circ}$ or at $10^{\circ}$ as described in Methods. The organisms in the remaining suspension were used to measure the glucosamine-accumulating capacity of the bacteria as described in Methods.

\begin{tabular}{|c|c|c|c|c|}
\hline \multirow{2}{*}{$\begin{array}{l}\text { Duration of } \\
\text { incubation } \\
\text { following } \\
\text { transfer of } \\
\text { cultures from } \\
30^{\circ} \text { to } 10^{\circ} \\
\text { (hr) }\end{array}$} & \multirow{2}{*}{$\begin{array}{c}\text { Temperature } \\
\text { of } \\
\text { incubation } \\
\left({ }^{\circ}\right)\end{array}$} & \multicolumn{2}{|c|}{ Respiratory activity } & \multirow[t]{2}{*}{$\begin{array}{l}\mu \mathrm{g} . \\
\text { glucosan } \\
\text { accumul } \\
\text { mg. dry } \\
\text { bacteriur }\end{array}$} \\
\hline & & $Q_{\mathrm{O}_{2} \text { end }}$ & $\boldsymbol{Q}_{\mathrm{O}_{2} \text { gluc. }}$ & \\
\hline $\mathbf{0}$ & $\begin{array}{l}10 \\
30\end{array}$ & $\begin{array}{l}3 \cdot 0 \\
6 \cdot 4\end{array}$ & $\begin{array}{r}1 \cdot 9 \\
35 \cdot 6\end{array}$ & \\
\hline 24 & $\begin{array}{l}10 \\
30\end{array}$ & $\begin{array}{l}3 \cdot 0 \\
2 \cdot 0\end{array}$ & $\begin{array}{l}3 \cdot 7 \\
6 \cdot 1\end{array}$ & \\
\hline 48 & $\begin{array}{l}10 \\
30\end{array}$ & $\begin{array}{l}2 \cdot 3 \\
1 \cdot 6\end{array}$ & $\begin{array}{l}2 \cdot 2 \\
5.7\end{array}$ & \\
\hline
\end{tabular}

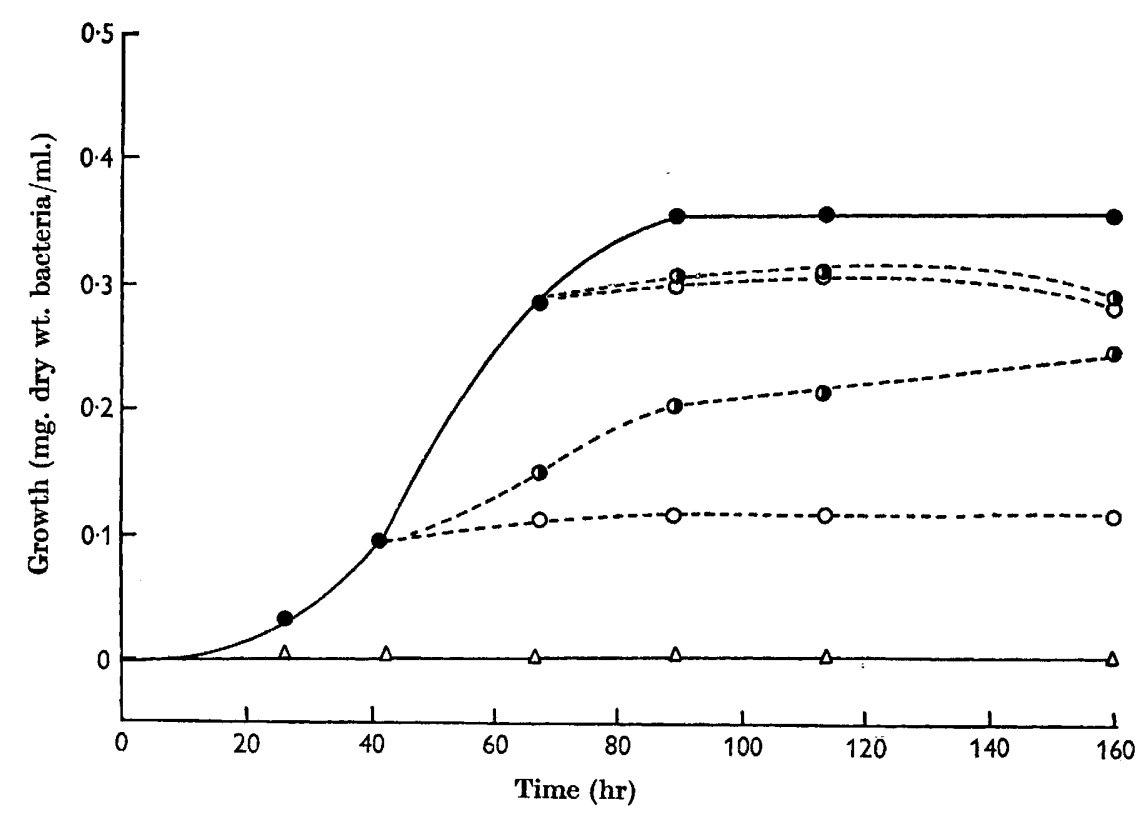

Fig. 2. Effect of change in incubation temperature from $30^{\circ}$ to $10^{\circ}$ or $15^{\circ}$ on the growth of Corynebacterium xerosis strain NCL. Cultures $(6 \mathrm{ml}$.) of the bacterium were grown at $30^{\circ}$ in Sameo tubes (-O). After $41 \mathrm{hr}$ and $67 \mathrm{hr}$, cultures were transferred to $10^{\circ}$ $(\bigcirc---\bigcirc)$ or $15^{\circ}(O---O)$. The graph also shows $(\triangle-\triangle)$ growth of cultures incubated at $10^{\circ}$ or $15^{\circ}$ immediately after inoculation. 
temperatures below the minimum for growth; experiments were therefore made to test this hypothesis. Cultures of the NCL strain of C. xerosis were grown at $\mathbf{3 0}^{\circ}$ and, when the cultures reached the mid-exponential phase of growth (after $40 \mathrm{hr}$ incubation) they were transferred to $10^{\circ}$. Bacteria in cultures transferred to this temperature did not multiply but continued to respire exogenous glucose and to accumulate glucosamine even after $48 \mathrm{hr}$ at $10^{\circ}$ (Table 2). Although cultures of C. xerosis NCL transferred from $30^{\circ}$ to $10^{\circ}$ did not multiply at the lower temperature, mid-exponential phase cultures of this bacterium transferred from $30^{\circ}$ to $15^{\circ}$ were capable of a limited amount of growth which corresponded approximately to a doubling in the size of the population (Fig. 2). Bacteria transferred in the lateexponential phase of growth did not have this ability to grow at $15^{\circ}$. The inability, or limited ability, of the bacterium to grow after transfer to a lower temperature was probably not caused by an increased nutritional demand by the bacteria at $10^{\circ}$ or $15^{\circ}$ since the same behaviour was observed in cultures grown in nutrient broth.

\section{DISCUSSION}

The minimum temperatures for growth of the mesophilic strains of Arthrobacter and Candida utilis examined in this study are probably determined, in part at least, by the inactivation of the mechanisms for transporting sugars into the organisms at temperatures between about $5^{\circ}$ and $10^{\circ}$. All of the psychrophils, on the other hand, grew well at $0^{\circ}$ and continued to transport sugars into the organisms at this temperature. Clearly the sugar transport mechanisms in these mesophils and psychrophils differ in their sensitivity to near-zero temperatures, but the results of experiments on the effect of metabolic inhibitors did not reveal any other differences between the transport mechanisms in the two groups of organisms. The similarity in the effect of 2,4-dinitrophenol on the sugar-accumulating capacity of the psychrophils and mesophils showed the need for metabolic energy for this process in both groups of organisms, while the sensitivity to uranyl ion indicated that the carrier molecules involved in the transport of sugars into both groups of organisms probably need to have phosphate groups free in order to function. The sensitivity of the mesophilic and psychrophilic Candida strains to the polyene antibiotic nystatin showed that sterols are present in the cytoplasmic membranes in both of the strains examined; by the same token, none of the psychrophilic or mesophilic bacteria would appear to contain sterols. The only previous report of a comparison of the properties of the sugar transport mechanisms in mesophilic and psychrophilic micro-organisms is by Cirilloet al. (1963), who showed that, in mesophilic and psychrophilic strains of Candida, these had the properties of a carrier-mediated transport.

In view of the lack of knowledge about the chemical nature of the solute carriers in cytoplasmic membranes, it is difficult to suggest a biochemical basis for the difference in the response to low temperatures shown by the sugar transport processes in these mesophilic and psychrophilic organisms. Kates and his colleagues (Kates \& Baxter, 1962; Kates \& Hagen, 1964) reported that the triglycerides and phospholipids from certain psychrophilic micro-organisms differed in composition from those extracted from related mesophilic organisms particularly with regard to the degree of saturation in the fatty acids and suggested that these differences in 
composition may be in components of the solute transport mechanisms (Baxter \& Gibbons, 1962). However, there is little evidence for the participation of triglycerides or phospholipids in transport processes in micro-organisms, and it is more likely that the carrier molecules are composed mainly, if not entirely, of proteins (Cohen \& Monod, 1957) which undergo conformational changes while effecting the transport of solutes. It is conceivable, therefore, that the protein carriers in mesophils become hyperfolded at low temperatures and are then unable to combine with the solute. Very little is known about the hyperfolding of proteins at low temperatures (Linderstrøm-Lang \& Schellman, 1959) although the phenomenon has been invoked to explain the inactivation of certain enzymes at temperatures just above and below $0^{\circ}$ (Kavanau, 1950; Maier, Tappel \& Volman, 1955).

It is clear however that, in the strains of Corynebacterium xerosis examined here, the minimum temperature for growth is not determined by the temperature at which the sugar transport processes in these organisms are inactivated, since these bacteria accumulated sugars at temperatures well below the minimum for growth. At present, it is only possible to speculate regarding the factors that determine the minimum temperatures for growth of these bacteria. One possible explanation is that, at temperatures below about $20^{\circ}$, they are unable to synthesize one or more compounds (e.g. nucleotides) that are essential for growth, but that, when transferred down from $30^{\circ}$ to $15^{\circ}$ in the mid-exponential phase, they are capable of a limited amount of growth at the expense of the stored reserves of these compounds. But the bacteria are unable to grow on being transferred down to $10^{\circ}$, and it is possible that, at this temperature, they are not able to use these stored reserves. Clearly, the biochemical basis of the minimum temperature for growth of C.xerosis is complex and probably involves the operation of a number of different factors. It is conceivable that one of the factors involved is a repression of enzyme synthesis which Ingraham and his colleagues (Ng, Ingraham \& Marr, 1962; Marr, Ingraham \& Squires, 1964) have demonstrated at low temperatures in Escherichia coli. It would also be interesting to discover to what extent the type of biochemical behaviour observed in C. xerosis at low temperatures is found in other micro-organisms.

This work was supported by a grant from the Department of Scientific and Industrial Research for which we are grateful. We also wish to acknowledge the excellent technical assistance of Miss Judith Hall.

\section{REFERENCES}

Ahmad, F., Rose, A. H. \& Garg, N. K. (1961). Effect of biotin deficiency on the synthesis of nucleic acids and protein by Saccharomyces cerevisiae. J. gen. Microbiol. 24, 69.

Baxter, R. M. \& Gibbons, N. E. (1962). Observations on the physiology of psychrophilism in a yeast. Canad. J. Microbiol. 8, 511.

Bergey's Manual of Determinative Bacteriology (1957), 7th ed. Ed. by R. S. Breed, E. G. D. Murray \& N. R. Smith. Baltimore: Williams and Wilkins,

Burger, M. \& Hejmova, L. (1961). Uptake of metabolizable sugars by Saccharomyces cerevisiae. Folia Microbiol. Delft, 6, 80.

Cirillo, V. P. (1961). Sugar transport in microorganisms. Annu. Rev. Microbiol. 15, 97.

Cirillo, V. P., Wilkins, P. O. \& Anton, J. (1963). Sugar transport in a psychrophilic yeast. J. Bact. 86, 1259. 
Cochrane, V. W. \& Tull, D. L. W. (1958). Uranium and spore respiration in Neurospora crassa. Phytopathol. 48, 623.

Cohen, G. N. \& Monod, J. (1957). Bacterial permeases. Bact. Rev. 21, 169.

GaLe, E. F. (1954). The accumulation of amino-acids within staphylococcal cells. Symp. Soc. exp. Biol. 8, 242.

Gomori, G. (1955). Preparation of buffers for use in enzyme studies. Meth. Enzymol. 1,138 .

INGRAHAM, J. L. (1958). Growth of psychrophilic bacteria. J. Bact. 76, 75.

InGRAham, J. L. \& Bailey, G. F. (1959). Comparative study of effect of temperature on metabolism of psychrophilic and mesophilic bacteria. J. Bact. 77, 609.

Kates, M. \& BAXTER, R. M. (1962). Lipid composition of mesophilic and psychrophilic yeasts (Candida species) as influenced by environmental temperature. Canad. $J$. Biochem. Physiol. 40, 1213.

KATES, M. \& HAGEN, P-O. (1964). Influence of temperature on fatty acid composition of psychrophilic and mesophilic Serratia species. Canad. J. Biochem. Physiol. 42, 481.

Kavanau, J. L. (1950). Enzyme kinetics and the rate of biological processes. J. gen. Physiol. 34, 193.

Lampen, J. O., Arnow, P., Borowska, Z. \& Laskin, A. (1962). Location and role of sterol at nystatin-binding sites. J. Bact. 84, 1152.

Linderstrøm-Lang, K. U. \& Schellman, J. A. (1959). In The Enzymes, 1. Ed. by P. D. Boyer, H. Lardy \& K. Myrbäck. New York: Academic Press.

Maier, V. P., Tappel, A. L. \& Volman, D. H. (1955). Reversible inactivation of enzymes at low temperatures. Studies of temperature dependence of phosphatase- and peroxidasecatalysed reactions. J. Am. chem. Soc. 77, 1278.

Marini, F., Arnow, P. \& Lampen, J. O. (1961). The effect of monovalent cations on the inhibition of yeast metabolism by nystatin. J. gen. Microbiol. 24, 51.

Marr, A. G., Ingraham, J. L. \& Squines, C. L. (1964). Effect of the temperature for growth of Escherichia coli on the formation of $\beta$-galactosidase. J. Bact. 87, 356.

Mitcheld, P. D. \& Moyle, J. M. (1956). In Bacterial Anatomy. Symp. Soc. gen. Microbiol. 6, 150.

NG, H., Ingraham, J. L. \& MarR, A. G. (1962). Damage and repression in Escherichia coli resulting from growth at low temperatures. J. Bact. 84, 331.

NorthaM, B. E. \& Norris, F. W. (1951). Growth requirements of Schizosaccharomyces octosporus, a yeast exacting towards adenine. J. gen. Microbiol. 5, 502.

RAHN, O. (1932). The Physiology of Bacteria. Philadelphia: Blakiston.

Rondle, C. J. M. \& Morgan, W. T. J. (1955). The determination of glucosamine and galactosamine. Biochem. J. 61, 586 .

Rose, A. H. (1963). On the osmotic behaviour of Saccharomyces cerevisiae as affected by biotin deficiency. J. gen. Microbiol. 31, 151.

Rose, A. H. \& Nickerson, W. J. (1956). Secretion of nicotinic acid by biotin-dependent yeasts. J. Bact. 72, 324.

Straka, R. P. \& Stokes, J. L. (1960). Psychrophilic bacteria from Antarctica. J. Bact. 80, 622 .

Umbreit, W. W., Burris, R. H. \& Stauffer, J. F. (1957). Manometric Techniques, 3rd ed. Minneapolis : Burgess Publishing Company.

Veldkamp, H., Van Den Berg, G. \& Zevenhuizen, L. P. T. M. (1963). Glutamic acid production by Arthrobacter globiformis. Antonie van Leeuwenhoek, 29, 35. 
